\title{
Climate Change and its socio-cultural impact in the Himalayan region of Nepal - A Visual Documentation
}

\section{Fidel Devkota}

\section{(2) OpenEdition \\ Journals}

Electronic version

URL: http://journals.openedition.org/anthrovision/589

DOI: 10.4000/anthrovision.589

ISSN: 2198-6754

Publisher

VANEASA - Visual Anthropology Network of European Association of Social Anthropologists

\section{Electronic reference}

Fidel Devkota, « Climate Change and its socio-cultural impact in the Himalayan region of Nepal - A Visual Documentation », Anthrovision [Online], 1.2 | 2013, Online since 01 August 2013, connection on 10 December 2020. URL : http://journals.openedition.org/anthrovision/589 ; DOI : https://doi.org/ 10.4000/anthrovision.589

This text was automatically generated on 10 December 2020.

(c) Anthrovision 


\title{
Climate Change and its socio-cultural impact in the Himalayan region of Nepal - A Visual Documentation
}

\author{
Fidel Devkota
}

\begin{abstract}
"Immense satisfaction, both personal and professional, can be attained through assisting a group of people in their struggles for a justice, fair play, health and welfare, and so on" (Waldram and

Dyck 1993:308).
\end{abstract}

\section{Introduction}

1 There has been limited research on the cultural context in the Himalayan region of Nepal with true anthropological significance and very few based on environment and people, as

" a relatively small group of anthropologists have contributed to understanding of how societies deal with environmental change and climate variability. Those contributions aside, the discipline is not strongly positioned in public debate about - or research and action on - anthropogenic global warming" (Butterbury 2008:62).

Himalayan region of Nepal was a forbidden land and was left untouched for political and geographical reason before 1950's. The history of scientific study and research prior to 1950 was limited. Only handful of researcher before 1950 were allowed in Nepal and most of them were based in Kathmandu. However the works of Krikpatrick (1811), Hamilton (1819) and Hodgson (1874) provide some information on trans-Himalayan trade and commerce and political significance. There are other significant travelogues from Chinese and Japanese monks and scholars visiting the region such as Ekai Kawaguchi (1909), whose work also sheds some light to the region, mainly in Lo-pa (Upper Mustang). According to Dhungel (2002), it was only after the annexation of Tibet and opening of Nepal in 1950's anthropologist and Tibetologist's from Europe and America began their research in Himalayan region of Nepal. Dhungel mentions that " the romantic fascination 
of 'western' scholars with Tibet and the Himalayan subject matter entered Nepal studies, and the northern frontier region of Nepal began to be viewed as an alternative location of Tibetan studies" (Dhungel 2002:24). Giuseppe Tucci (1953), a Sanskrit and Buddhism scholar from Italy is credited as a pioneer of cultural and historical study of Himalayan region of Nepal in the 1950's. Christopher Von Furer Haimendorf (1964) is considered to be the first anthropologist working on rituals, religion, and social values in the region (Dhungel 2002).

\section{Background}

3 Nepal is a landlocked country, which lies along the southern slopes of the Himalayas. It is about $900 \mathrm{~km}$ from east to west and between 150 and $250 \mathrm{~km}$ from north to south and is bounded by the India to the east, south and west and the Tibet region of China to the north (Spence 1987:223). Nepal is not just about nature, but also a melting pot of people with distinct culture, language and religion. It is generally "thought that the entire Himalaya region served historically as a place of refuge for diverse cultures fleeing imperial conquest. This is a complex issue, but it partially accounts for the current ethnic and territorial diversity in the area" (Zurick 1989:233). Topographically, Nepal is divided into three distinct regions running laterally across the country - Himalayan (above 4,877 meter), hills (610-4,876 meters), and terai (flat land) belt runs up to an altitude of 609 meters above the sea level (Upadhyaya 2010:2). Himalayan region occupy 35.2 per cent of the total land area of Nepal but provide a home for only 7.8 per cent of the total population (Census 1991) and according to the census in 2001, the total population of Nepal was 23.1 million and the shows the slight decline in Himalayan population to 7.3 per cent (Census 2001) but the importance of the region is immense as the economy of the country depends on agriculture and tourism for which the Himalayan region is extremely important.

4 Climate Change according to World Bank Report is any change in climate over time, weather due to natural variability or as a result of human activity (Ahmed et al. 2009) which is slightly different to that of UNFCCC which describes it as "a change of climate which is attributed directly or indirectly to human activity that alters the composition of the global atmosphere and which is in addition to natural climate variability observed over comparable time period" (UNFCCC 1992:3). According both the above mentioned definition humans will be directly affected and this could be the defining 'human development' challenge of our time (Ahmed et al. 2009). This puts the Himalayan region of Nepal in vulnerability zone. Sudden change in climatic pattern has threatened the livelihood of the rural poor. Clear indications of these impacts can be seen on Himalayan glaciers, which are melting rapidly. Food scarcity and malnutrition, diseases such as malaria and dengue fever are moving to higher altitudes. Water-borne diseases have visibly amplified, accompanied by the lack of safe drinking water and basic sanitation in the region. Deaths and morbidity associated with extreme and erratic weather has increased. Climate change is and will impact, more severely to the children, women, marginalized and poor people and community (Shrestha 2009, Rai and Gurung 2005) even though it can be too early to blame it all on climate change factor for such changes.

The Himalaya is renowned for high altitude settlements with distinct physical setting and pattern. However, most anthropologist working in this region "define Himalaya not only with the respect to the geographical but also to the historical, linguistic, political, 
cultural, structural, ecological and even psychological dimension of the region and of its people" (Dahal 2008:50). Therefore it is important as an anthropologist witnessing the social transformation to know "what kind of cultural techniques do local people utilize for the sustainable use of natural resources and the prevention of and adaptation to Natural Hazards" (Froemming and Reichel 2011:228) as understanding its impact on culture and people of our time and responding successfully to them will be a major test for mankind and civilization. Crate and Nuttall suspect that environmental and cultural change is happening far beyond the reach of restoration (Crate and Nuttall 2009). I believe that anthropology can play a vital part in such times of change and transition. Even though no society/ individuals can stop climate change, as Hassan puts "efforts can be made to minimize vulnerability to the deleterious impact and enhance the resilience of the social system" (Hassan 2009:61). And this research is an effort with the role of activist, witness, advocate, and a medium to contribute to the societies of Himalayan region and elsewhere.

\section{Research Site}

6 Lo-pa (Upper Mustang) is located in the trans-Himalayan region of north-western Nepal. It has an area of 780 sq. mile (Dhungel 2002) and is divided into seven Village Development Committee (VDC) namely, Chuksang, Ghami, Tasarang, Lo-Manthang, Chosser, Chonup and Surkhang. Upper Mustang has the population of 5395 (Census 2001). Most of Upper Mustang doesn't have a monsoon climate of rest of Nepal as it falls in 'Rain-Shadow' zone (Baidya et al. 2007). Upper Mustang is also is known for its severe winter and is one of the coldest region of Nepal as temperature drops up to -20 degree to -30 degree Celsius and in summer it stays between 0 degree to 10 degree Celsius (Dhungel 2002).

7 The inhabitants of Mustang are "culturally, linguistically, and ethnically similar to the people of western and central Tibet" (Dhungel 2002:14) and the aristocratic house of the region has a matrimonial relationship with several of the highest aristocratic houses of Lhasa including last monarch of Mustang. Inhabitants of Upper Mustang are mostly Lo-pa people of Tibetan ethnicity (Dhungel 2002). The population "compromise of three caste or social groups-the Bistas, who comprise the Mustang royalty and the aristocracy, the Gurungs- who form the bulk of the population and the Biswakarmas, the lowest in the social rung are the occupational caste group (SYC 2011:6). Even though monarchy has been abolished from Upper Mustang, king of Mustang has a considerable privileges and traditional authority and power. Village chiefs (mukhiyas and kutwals) and the monastery also have considerable influence with respect to socio-economic and cultural affairs.

Dhe (Dhye or Dewa) Village:

9 Surkhang is the largest VDC in Upper Mustang covering the area of $784.16 \mathrm{sq} . \mathrm{km}$ and the population is 515 with 114 households (SYC: 2011). Surkhang VDC has six settlements namely, Di, Surkhang, Yara, Ghara, Dhe and Tangye. Dhe village of Surkhang (Ward no. 9) is one of the smallest and isolated villages of Upper Mustang, which lies about 20km east of Tsarang (see figure 1). The village is $3860 \mathrm{~m}$ above sea level and it has a moderate weather in summer and severe winter. There are now 24 houses; with approximately 150 people and around 1000 livestock live in the village (see table 1). According to the people of Dhe, they migrated to current location from Nakkali- Damadorkunda, which is 2-3 days walk up to the northeast near Tibetan Border. Dhe villagers still use that area for pasture. 
Dhe people believe that from Nakkali- Damadorkunda they moved to 'Zhong' or the Caves that lies 200-300 meter direct below the current settlement. There are around 30-40 caves of different sizes and some still in use by monks and villagers for religious purpose (Devkota 2011).

Figure 1. Location of Upper Mustang and Dhe Village in the Map of Nepal

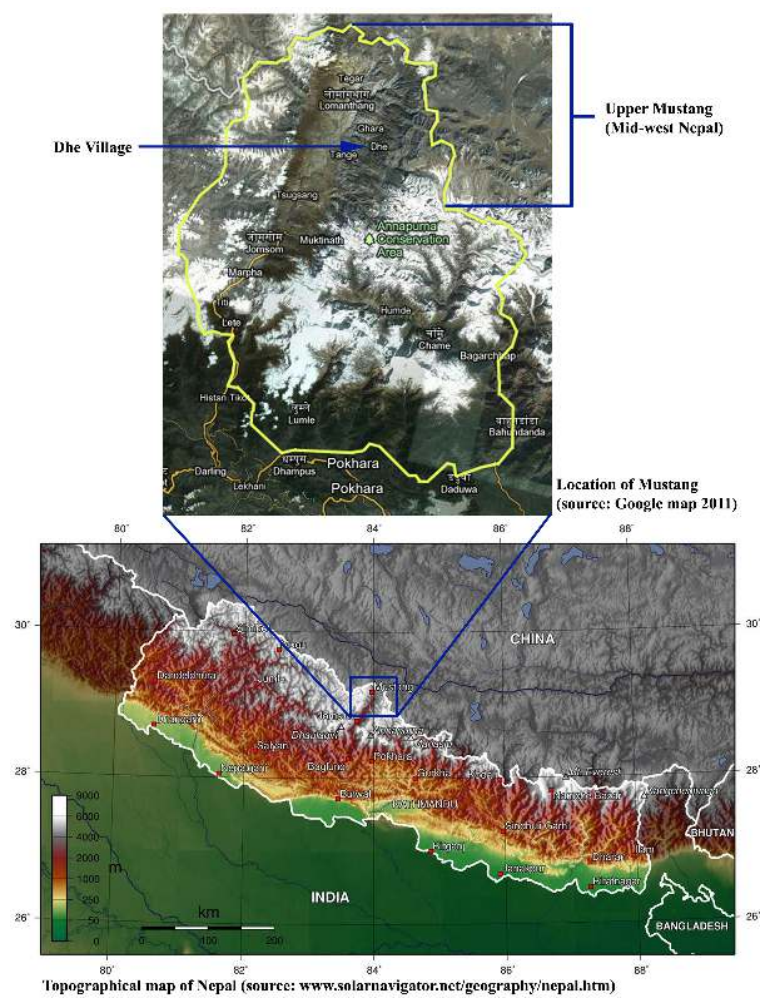

Figure 2. Settlement of Dhe Village

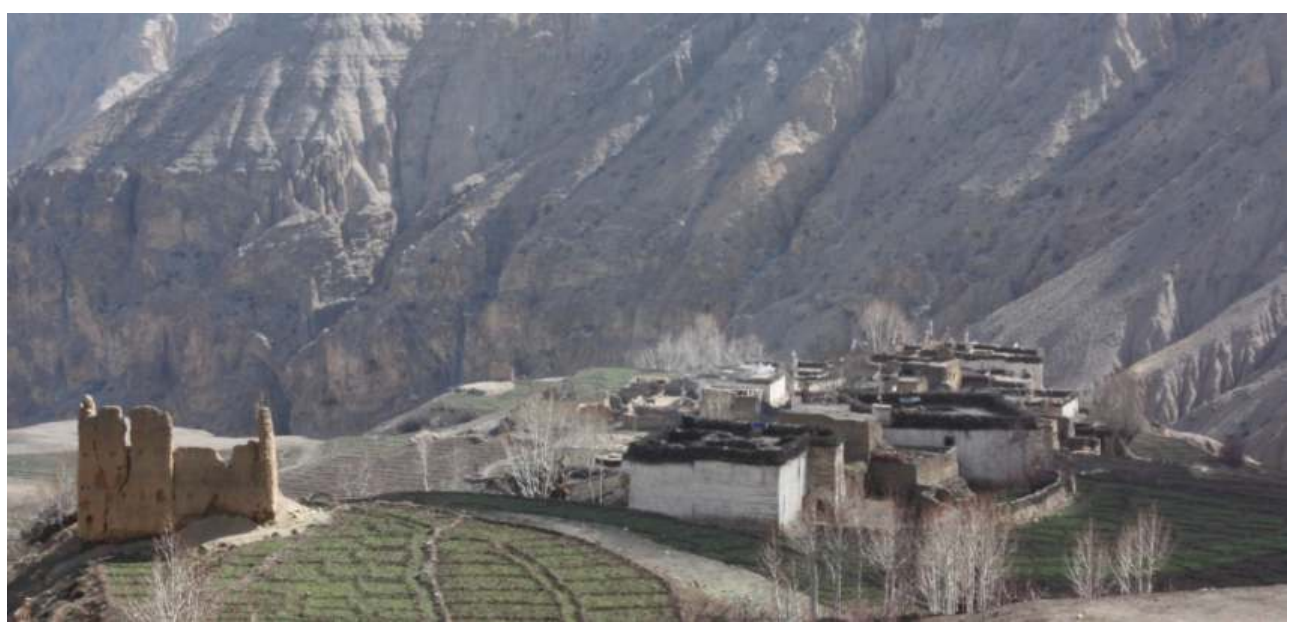

List of 24 households of Dhe Village (Table 1)

\begin{tabular}{|l|l|l|l|}
\hline Number of household & Head of the family & $\begin{array}{l}\text { Number of family } \\
\text { member(s) }\end{array}$ & Current location \\
\hline
\end{tabular}




\begin{tabular}{|c|c|c|c|}
\hline 1 & Decchen Gurung & 3 & Dhe \\
\hline 2 & Dorje Chopten Gurung & 8 & Kathmandu \\
\hline 3 & \begin{tabular}{|l} 
Jamyang Wangchuk \\
Gurung
\end{tabular} & 10 & Dhe \\
\hline 4 & Karma Gurung * & 7 & Dhe \\
\hline 5 & Kungsan Rinzin Gurung & 8 & Dhe \\
\hline 6 & $\begin{array}{ll}\text { Norbu } & \text { Wangchuk } \\
\text { Gurung } & \end{array}$ & 2 & Tsarang \\
\hline 7 & Pasang Gurung & 9 & Dhe \\
\hline 8 & Pasang Wangdu Gurung & 5 & Dhe \\
\hline 9 & Pema Doma Gurung & 2 & Dhe \\
\hline 10 & Pema Tsewang Gurung & 6 & Dhe \\
\hline 11 & Sangbo Gurung & 7 & Dhe \\
\hline 12 & \begin{tabular}{ll|} 
Sonam & Gyaltsen \\
Gurung &
\end{tabular} & 4 & Dhe \\
\hline 13 & Tachung Gurung & 5 & Chuksang \\
\hline 14 & Tashi Choden Gurung & 9 & Dhe \\
\hline 15 & Tashi Chopel Gurung & 13 & Dhe \\
\hline 16 & Tashi Phuntosk Gurung & 12 & Tsarang \\
\hline 17 & Tashi Rinzin Gurung & 4 & Muktinath \\
\hline 18 & Topri Gurung & 3 & Dhe \\
\hline 19 & Tsering Butti Gurung & 4 & Jomsom \\
\hline 20 & $\begin{array}{ll}\text { Tsering } & \text { Choedup } \\
\text { Gurung } & \end{array}$ & 12 & Tsarang \\
\hline 21 & Tsering Dhake Gurung & 8 & Dhe \\
\hline 22 & Tsering Largyal Gurung & 7 & Pokhara \\
\hline 23 & $\begin{array}{l}\text { Tsonam } \\
\text { Gurung }\end{array}$ & 7 & Dhe \\
\hline 24 & Yangchen Gurung & 1 & India \\
\hline
\end{tabular}


Total population: 147 (it is based on the data provided by the villagers)

(Note: exact number was not possible because the villagers are not sure of the new number of persons in the family of migrated villagers)

* (Karma's family doesn't have a land in Dhe but lives a nomadic life in region)

\section{Methodology}

\section{Anthropological Discourse}

10 What Anthropologist has to offer is primarily a systematic way of understanding humanity - our as well as everyone else's (Ruby 1980:161) and the 'big' questions that engaged anthropologist since the beginning of the discipline: "what is so unique about human beings? how are groups of people-family, class, tribe, nation - formed and what holds them together? what is the nature of belief, economic exchange, the self? how are we to go about researching and understanding such things" (Monagham and Just 2000:11-12)? Anthropology apart from answering the above mention questions has deeply evolved and involved in vivid richness that comes out of specific meetings and encounters anthropologist/ethnographers have with particular peoples and places. In Anthropology and particularly ethnography both a process and the product are equally important as Agar explains "ethnography is not simply 'data collection'; it is rich in implicit theories of culture, society and the individuals (Agar 1980:23)" and I have tried to find some knowledge and understanding that can be shared within the mountain people of the region and beyond. As anthropology has long been engaged in "relating the description of local beliefs and practices to categories of universal, pan-human significance" (Monagham and Just 2000:20).

11 I begin my film with a high-ranking 'amchi' (doctor) talking about the Buddhism and its relation to environment and relating it to the current problem of Dhe village. I am trying to relate it to pre-climatology and scientific records, because at that time "change of climate within narrow span of human memory were thought to be the works of god and the only human recourse was propitiation through prayer, sacrifice, and temple building" (Fagan 2005:247-248). My approach here has nothing to do with the 'classic' anthropologist/ethnographers of 1930's and 1940's - a period where the communities were presented as frozen in time, outside any historical context, and without reference to neighboring societies or encapsulating states (Monogham and Just 2000) and I am only referring to the geo-political distance of the region with the center.

My research is based on four important questions referred by Roncoli et al. - "how people perceive climate change through cultural lenses ("perception"); how people comprehend what they see based on their mental models and social locations ("knowledge"); how they give value to what they know in terms of shared meanings ("valuation"); and how they respond, individually and collectively, on the basis of these meaning and values ("response")"(Roncoli et al. 2009:88) and my assumption that this elements of human experience are best represented visually or with the words of Sarah Pink "the visual brings the fieldwork experience directly on to the context of representation" (Pink 2006:16) in the discipline of words (Mead 1995). My main motivation of choosing visual medium is as Asch puts it, 
"Cultures are now under ferocious pressure to change and change quickly, many will disappear. That is why anthropology and ethnographic film-making are so important" (Asch 1992:204). documentation are that the evidence provided is available to the view of many individuals both immediately and for a period" (Gardner 1957: 345-346). It was important for me as an anthropologist to recollect and represent memories of people who move between time and culture with the help of cinema because Dhe villagers have already lost a substantive part their history and memories of their previous settlement.

\section{Observation (Observational and Participatory Observation)}

14 I have used observational cinema as the foundation of my research as "Filmmakers working broadly within an observational film paradigm, it to encourage the film subjects to speak for themselves, to convey- or be prompted to convey - a board spread of background information necessary as context for the film's main narrative"(Banks 2001:150). I do not have an established protagonist in my film, as I wanted the whole village to be the central character, but I choose a villager named Topri Gurung ( $55 / \mathrm{male})$ as a representative for the village. The reason behind Topri Gurung's selection was, he is active, well respected in the village, he is an elected 'kutwal' (second head) of the village, and he has a good command of Nepali language and he was willing to support for the 'mutual' cause. But at certain point during the research, I was not happy to be content with mere observation, so 'on the ground for experimentation' established by observational cinema (Grimshaw 2005). I tried to 'facilitate' beyond it, as I found out operating only on observational mode was not sufficient to express myself. As a researcher and a filmmaker on given situation as Nichols said Participatory " gives us a sense of what it is like to for the filmmaker to be in a given situation and how that situation alters as a result" (Nichols 2001:116). Therefore I took a participatory and reflexive role of an anthropologist in few scenes of the films. It allowed me to interact with people, deepening our relationships and trust and to extract the depth of local knowledge, understanding and dialogue. This was vital for taking field-notes in depth and for anthropological understanding in whole. Sometime I found myself just filming in the spirit of Vertov's 'Man with a movie camera' (1929). I was also aware that "Fieldwork does not place human interaction outside the research paradigm: instead, the paradigm is based upon human interaction, in all its richness, variety, and the contradiction"(Cassell 1980:31), and in my research such interactions were flowing freely in both directions but in doing so I was also aware that "Participant observation means that you try to experience the life of your informants to the extent possible; it doesn't mean that you try to melt into the background and become a fully accepted member of the culture other then your own" (Bernard 2011:293). It was easier for me to be accepted because I am also a mountain people just like them.

\section{Use of Audio / Visual medium}

The ethnographic data generated from the audiovisual technology have various uses, as mentioned by Schensul et al. " ethnographers are interested in capturing behavior, thoughts, feelings, and products that provide insights into cultural phenomena in order to better understand human behavior within the context of culture and to design 
interventions to effect individuals and/or cultural change" (Schensul et al. 1999:40). Audio/Visual medium gave me the possibility of reviewing, analyzing and interpreting data for unlimited time. Although ethnographers basically depended on written records to capture the answers from their subject, or note their observation in natural context and the techniques of Audio-Visual, which provide an alternative or supplement to the extensive written record which is the hallmark of traditional ethnography (Nastasi 1999:1) and anthropology in general. My use of Audio/Visual is not just to supplement but look for alternative approach to anthropology through visual mediums. As said by Asch the emergence of film has given "humankind unprecedented opportunities to experience vicariously the details of life in unfamiliar, often distant and isolated places (Asch 1992:196) and I wanted to explore it believing in what MacDougall said, "images and written texts not only tell us things differently, they tell us different thing" (MacDougall 1998:257).

\section{Interview}

Local people of Upper Mustang in general speak Tibetan language as their mother tongue. According to the local, they say that their dialect is similar to the central and western part of Tibet. The dialect they speak in Upper Mustang is called Lo-pa. Most of the younger generations of the region speak perfect Nepali, as Nepali is the official language, which is also the medium of language in schools. Older generation, mostly men speak Nepali and even some other local language because they spent about 4-5 winter months every year selling Jimbu (Allium hypsistum) herb in lowland. Most of women and children who haven't been to school or to the lowland cannot communicate in Nepali.

My protagonist Topri Gurung from Dhe speaks good Nepali. Topri's wife Kunga Angmo Gurung also speaks good Nepali with heavy Lo-pa accent like Topri, which is normal to the people of the region (see figure 3). The other collaborators (Dhycho Bista, Pasang Gurung, Tsering Larkke Gurung) also speak fluent Nepali and Tibetan. My Tibetan skill is limited to normal conservation so almost all of my interviews were conducted in Nepali except that of head monk of Tsarang Gompa and few females from Dhe. Topri Gurung helped me explain things with other villagers in Tibetan language, which made it easier to communicate. 
Figure 3. Topri Gurung and his wife Kunga Angmo Gurung from Dhe Village

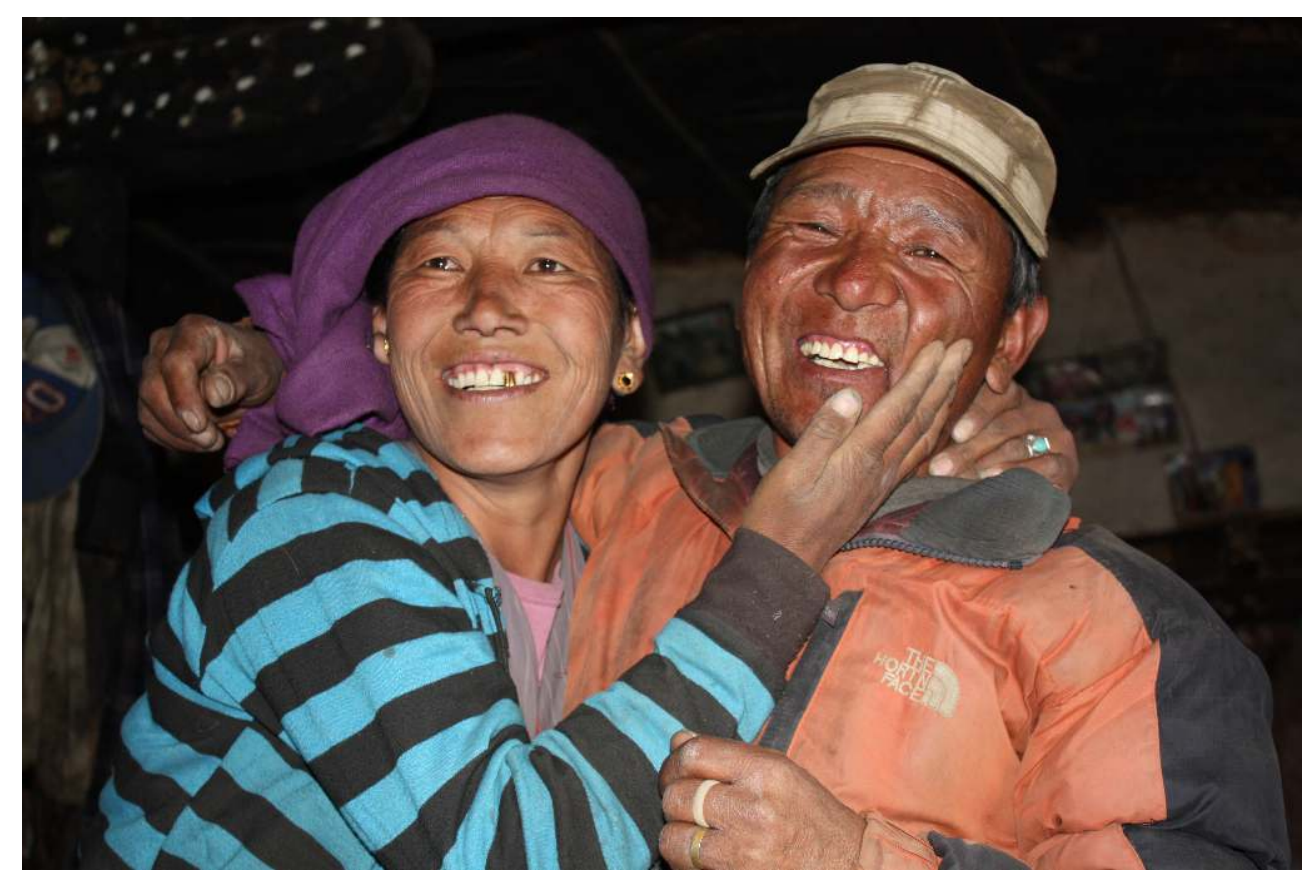

Most of my interviews were improvised with out any formal structures and guidelines. I was using the tipped information from different nearby villages. When I was in Tsarang, I asked to the locals about Dhe people and if they know anything about the current situation of Dhe . Locals of monks of Tsarang village gave me various informations, myths and history of Dhe Village. Most of the people outside Dhe believed that the current problems of Dhe related to the selling of fossil stones and killing a yeti by the Dhe locals that is why the god is angry with them. When I was in Dhe, I used this information for our conversation and interview so we were always moving forward and there were lots of new information coming out in the process. They told me whatever they wanted to say and I asked what I wanted to ask. It was a mutual process with information was flowing both ways.

\section{Post production}

I shot approximately 700 minutes of visual footages, and more then 10 hours of separate sound material and about 2000 (plus) photographs from my fieldwork in Dhe, LoManthang and Samjhong of Upper Mustang. To make a 40-50 minute film out of the material was a challenge for me, also because I was editing it on my own. I found it quite hard to detach myself from the footages because they are so special and will always be.

I choose only to use footage from Dhe for my thesis because of the time constrain and other technical reason. From my research I found out that the problem of Dhe is similar to the problem of other villages such as Samjhong, but there are also some different local problems of each village, but for this research I will be focusing on common problem of the region with special focus on Dhe. I will use the footages from other sites in my followup research.

Ethnographic film documentation must satisfy certain terms because it is scientific venture and as mentioned by Fuchs "unity of the place, time, group, and action, together 
with the strict obedience to the chronology of action in the final version of the film" (Fuchs 1988:222). It was always a challenge to edit the film, but no matter how extensively and meticulously we work during production and post-production phase, the final outcome still remains the selective amount of what actually happened. From my experience filming and editing the footage of the fieldwork, I do agree with the expression of MacDougall that the "footage is some kind of unmediated evidence that contains the 'truth' about external reality... editing does in fact introduce its own higher order of truth and understanding" (MacDougall 1998:215). I do have to admit that there is more depth in knowledge and representation in my rushes then in the final film. With the length I also lost some context on postproduction.

One of the important parts of postproduction process was subtitling the film. MacDougall said that subtitling is "open to error and abuse, for it has the potential to make people say whatever the filmmaker want to say" (MacDougall 1998:167). And when I was subtitling the film I found out that it was quite hard at times to match the essence of the voice with the words. I think there will always be some meaning lost in translation. As different language and different people require different lengths of time to express similar ideas, it may change the pace of the film and flow of information through subtitles, and as MacDougall further adds that subtitle forces a compromise between length and nuance of the film (MacDougall 1998), which is clearly visible in some parts of my film. For me it was also particularly hard to use the information from the subtext because of my limitations with the Tibetan language.

\section{Ethics}

Upper Mustang was closed to foreigners before 1992, and since then it has been placed under semi-protected region because of the sensitivity of the cultural pattern of the region. As I was doing a research and filming in the region, I was working with extra responsibility and I was also aware of the fact that "exposure to the outside world can be occasionally pose grave dangers to the people and societies" (Asch 1992:197). First I took written permission from the Annapurna Conservation Area Project (ACAP) headquarter in Pokhara, which is under the Ministry of Environment (MOE).

The development of trust between local communities was vital to my research and film project. Dhe villagers trusted me and gave access to the insight of their life and culture, which was not possible without mutual trust and respect. As stated by Asch our trust constituted an unwritten contract, which brought certain obligation and ethical consideration into play (Asch 1992: 196). I have always been critical of early and even recent ethnographical works where the subjects are degraded and even abused. I didn't design my film "to shock, but to bridge a cultural differences" (MacDougall 1992:90) and it was always a challenge for me to produce a film belonging equally to two different cultures. "I view the process of filmmaking as a collective one, that is, I cannot film at, but only with people" (Freudenthal 1988:124), the very people I have to 'represent' with their high held dignity and pride. "The ethics of the complex exchange relationship of fieldwork require that researchers be prepared to use considerable amount of their financial resources, skills and information for the benefit of the people who supply them with data in the long hours and days of the fieldwork enterprise" (Pelto and Pelto 1976:539-540), and as an anthropologist, I tried to be a collaborator, felicitator and mediator between the locals and the global. 


\section{Results and Findings}

\section{Changing landscape}

Climate change is having a noticeable impact on the environment of Nepal and its even severe in the Himalayan region (Upadhaya 2010). Even though my film project was entirely based on Dhe Village, I spent few weeks in other villages such as Tsarang, LoManthang and Samjhong to have a clear picture of the region. According to the details and fact that people provided to me and from my own observation, impact of climate change is distinctly visible in the region, but it may not be entirely due to global warming.

In his book 'The Kingdom of Lo (Mustang)' Dhungel presents an interesting fact and I also noticed it myself that the region of Upper Mustang had monumental palaces, gompas, and shrines, which proves its prosperity at the time. Most of these were built around 14-15 century but after $16^{\text {th }}$ century there has not been any remarkable constructions in the region (Dhungel 2002) and the current situation may have started by then. Landscape of the region is changing due to glaciers melting and desertification of the land.

27 I took countless interviews in Dhe and other part of the region and I have included three such interviews in the film where the villagers talks about their experience which shows that the region is changing.

Topri Gurung (55/m): "Everything was good here, when I was a child. I used to take herd of small goats for grazing up in the fields, which used to be all green" (Devkota 2011: 4').

Pasang Gurung (37/m): “ It used to snow heavily in the past which was good for us but now a days there is not that much of snowfall, and if doesn't snow, water source also starts to dry and may be that is the reason of our problem" (Devkota 2011:7').

Tsering Larkke Gurung $(45 / \mathrm{m})$ : "in our forefathers time there used to be thousands and thousands of animals with enough grass to feed on...but now we hardly have one thousand animals and they do not have enough to graze" (Devkota 2011:28').

Topri Gurung and Wangel Gurung $(74 / \mathrm{m})$ showed me the old water channels and deserted fields of Dhe. According the villagers and Topri Gurung $2 / 3^{\text {rd }}$ of field is abandoned now due to lack of water for irrigation (Devkota 2011).

Villagers also told me that they used to have at least 1 or 2 ponds per household, and the water collected on these ponds used to be sufficient for irrigation. But now they hardly have 5-6 ponds full of water in the peak season (April/May). Most of the ponds on the top of the villages are flat dry and the villagers now collect water in communal ponds and use in rotation (Devkota 2011). It is still not enough to irrigate the all-useable land. Villagers are abandoning more and more pieces of their land every year and the landscape of Dhe looks completely arid and deserted now (see figure 4 ). 
Figure 4. Barren and abandoned fields of Dhe Village

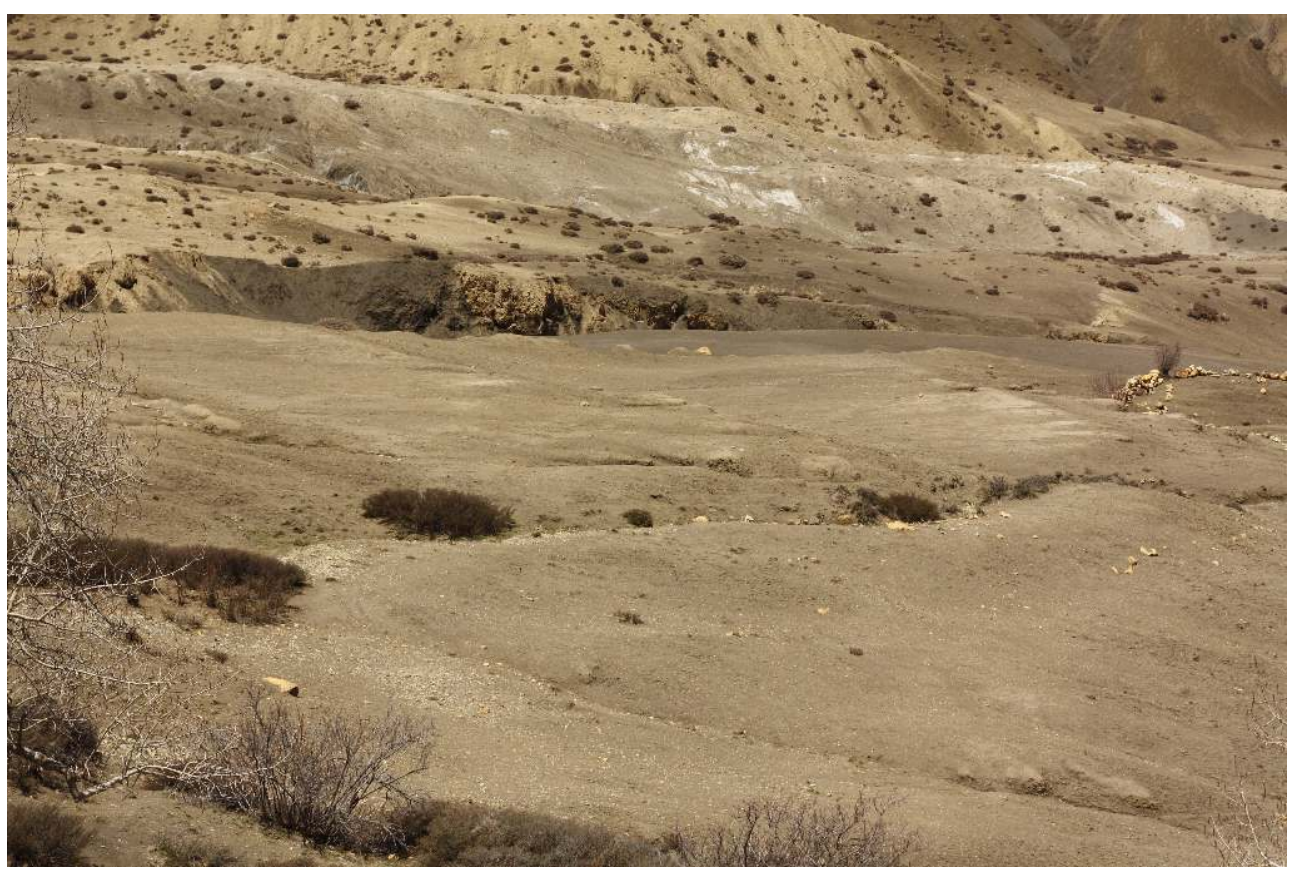

\section{Myths from the mountains}

Buddhism is the main religion in Upper Mustang with reminiscence of shamanistic and bonpo traditions. There are many myths related to the current problems of Dhe. A fifthgeneration and a well-known amchi from Lo-Manthang explained the relation between people, environment and Buddhism,

"According to Buddhism, we have to conserve environment. We should not cut old trees because 'ying' stays there which will curse us, 'naga' lives in our rivers and water holes, and if we disturb it- there won't be rainfall and will also give us health related problems. We shouldn't disturb big mountains because 'chen' lives there and it will also curse us. We are not following the rules of Gautam Buddha, therefore the nature is punishing us for our actions. Dhe is really a small isolated village in the mountains, according to our Buddha-dharma and mountain beliefs there exists 'heula' which is the village deity. We have to worship and pray for it often and if we fail to do so it will get angry and will cause hailstorms and all sorts of other calamities. So the problems of Dhe may be related to the curse of the 'heula"' (Devkota 2011:1').

Tashi Tsering $(46 / \mathrm{m})$, a high ranking Lama of Tsarang Gompa gave me some more myths related to the problems of Dhe. According to one of the myth - Dhe Villagers killed a snowman or a yeti and skinned it. Killing of this mythical yeti may have cursed the village (Devkota 2011). Dhe villagers and Wangel Gurung who was a part of the incident verified the story. Tashi Tsering Lama also gave me another reason and linked it to the current problems of Dhe. Dhe river and a part Dhe village is said to be the source of fossils stones ( Saligram) found in Kali-Gandaki river. Hindus and Buddhist consider such stones to be sacred. Dhe people were involved in collection and selling of such holy stones (see figure 5), which may have caused the current problem (Devkota 2011). 


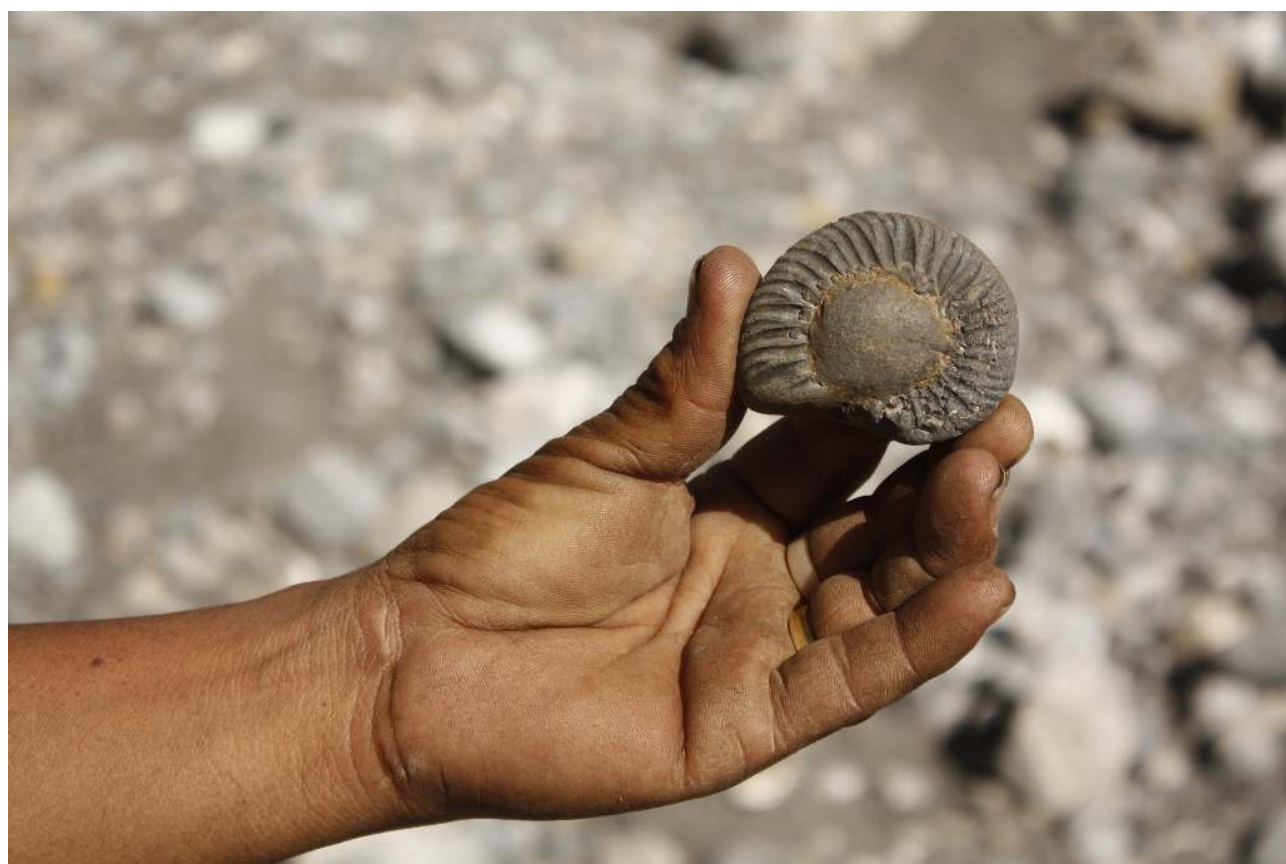

People of Dhe strongly deny any foul play or wrongdoing. They believe that it is their destiny and nothing else. Pasang Gurung says,

"We tried if the lama's praying and recitations will ease the situation. We believe in it and we tried everything according to our tradition and culture. We tried everything- it's hard to believe that it happened because 'heula' is angry with us" (Devkota 2011:8').

When I asked about the fossil-stone business with the villagers, they told me that it's their right to sell the stone and earn some money from it because the stone is from their land. There are other stories and myths associated with the place and region, which can also be related to the current problem of the region, but it will require a close study and analysis before coming to any conclusions.

\section{Socio-economic factors}

\section{Food production}

People of Dhe village mostly dependent on the crop of barely, wheat, buckwheat, oats, mustard, potatoes, and peas for staple diet which also includes meat and dairy products. Agriculture is main source of livelihood in the region, but not even fifty per cent of the people of region have enough farming land to support themselves (Dhungel 2002) and the amount of food produced is simply not sufficient to feed the people for the whole year. They buy mostly wheat-flour and maize from the nearby markets and Tibet. Rice is not produced in the region at all, and according to Topri Gurung, it's a luxury "we eat rice only in the festivals like yartung and loshar (Devkota 2011)". They normally barter rice with jimbu herbs in the lowland. As the collection of jimbu herb is also affected due to the adverse climate, rice is getting costlier for the Dhe villagers. The food security is at risk because several bad years with severe weather have affected crops growing cycle. 

agriculture (Gum et al. 2009) and due to less precipitation and snowfall, the fields are deteriorating. Due to the lack of assistance, resource and information they are just abandoning their land. People of Dhe say that they are not even getting the amount of grains they planted on the field (Devkota 2011). Villagers are finding it hard to cope with erratic weather pattern because the severity is such that their indigenous knowledge no longer has the answer or understanding. Intergovernmental Panel on Climate Change (IPCC)'s report shows that the crop yield in many countries of Asia has declined, partly due to the rising temperature and extreme weather events and rainfall variability (Cruz et al. 2007:471), same report also predict risk of hunger and scarcity of water resource which is already taking to place in Upper Mustang.

Figure 6. Dhe Villagers working on the field

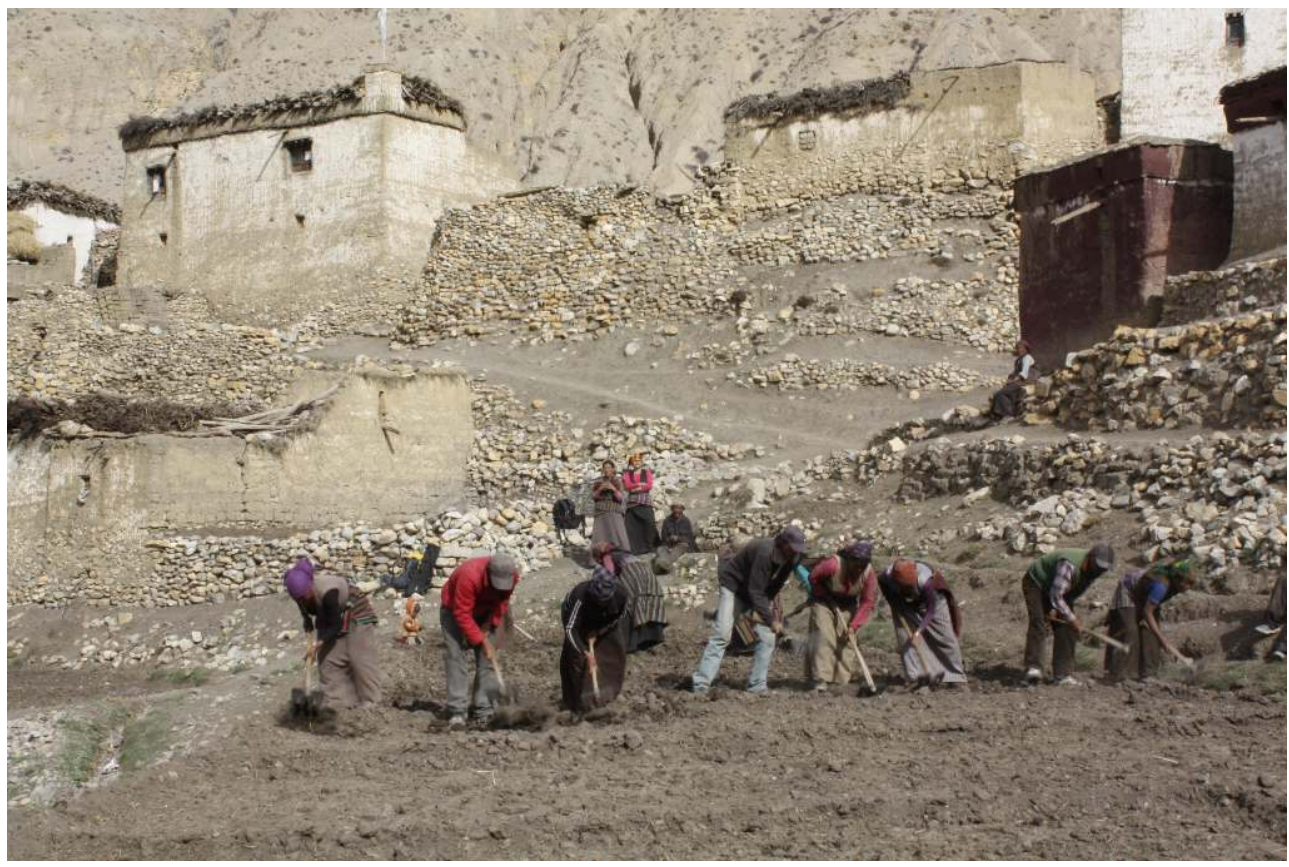

Even productive agricultural fields with access to irrigation are being affected by the landslides and flood due to the melting glaciers located in the north (Dhungel 2002). Natural calamities have forced villager to sell their cattle in numbers every year for buying food and vegetables and without the purchasing power they are in the risk of starvation. Every year there are considerable numbers of cattle sold in every household. The villagers are now in a dilemma of sustaining life once all the cattle are gone. During my fieldwork I also found out that the dependence on bought food has brought changes in the eating habit. Topri Gurung and other villagers complained that traditional staple diet of Dhe villagers such as 'tsampa' or 'sattu' is not popular to the younger generation who prefer cheap biscuits and ready-made instant noodles more. Rice and potato (mostly bought from outside) is slowly replacing wheat and barley as a staple food.

\section{Animal husbandry}

People in Himalayan region have a close relationship with animals. Animal husbandry plays a vital role for the survival of the people especially in "drier parts where production 
systems usually are based on some form of pastoralism, which involves seasonal mobility of herds and people between grazing areas" (Anderson et al. 2010:204). This is the case with the people of Dhe where animals are not just use for transportation and meat and dairy purpose but also for clothing's and in recent times to generate cash from the sale of animal and wool. Animal husbandry is a vital economic resource of Lo-pa region and Dhe village. People's

"livelihood is still based equally on herding of domestic animals such as yak, Dzo, ba-lang (cow), horse, mule, donkey, goat and lamb. Since Lo-pas have already had very limited arable land, individual of family property was calculated mainly on the basis of livestock holdings" (Dhungel 2002:17).

During my research I found that the family of Wangdel Gurung is rich and prosperous because they have the only yak herd in the village and two sons of the family Tashi Larke Gurung look after cattle, Pasang take cares of the small scale trade with Tibetans and their wife Dolkar Gurung (polyandry marriage) is in-charge of the household with her father in law. This is also a typical case of a polyandry family. In recent time the sharp decline in numbers of animals due to lack of pasture and raising temperature is causing a social and economical problems. There is no practice of growing fodder-crop in the region (Donner 1968:33), which is still the case; therefore it is hard for the people of the region to feed animals once the wild pastures starts to dry. The decline in number of animals is directly related to the availability of the pasture in the region.

Most of the villagers who have flocks of goat (around 150-200 maximum) can earn around forty-fifty thousand Nepalese Rupees (NRs.) a year by selling wool to Chinese businessmen (Devkota 2011). Cash is vital to the economy of the village, and if the land and climate deteriorates in current rate, there will be a decline in numbers of cattle. This means a massive decline in income from the sell of dairy products like butter and ghee and dry cheese. Due to decline in purchasing power villagers are forced to sell their remaining cattle to buy food and cloths.

\section{Cultural Implications}

43 Livelihood and survival of the people of the region is closely related to the piece of their land and number of their cattle and if it is affected by the sudden change in climate pattern then it will for sure has its consequences on the cultural aspect of life.

For centuries people of the region has been celebrating their main festivals such as loshar and yartung together in the community. Each house contributing grains to make food and chang (local beer) and preparing a feast for the whole village. Eating, drinking, singing and dancing used to be the part such festivals. As the food-production is decreasing in alarming rate and the numbers of cattle dwindling, villagers are finding hard to continue their traditions. One of the most important festivals of Tiji which is celebrated in LoManthang with all village of Lo-pa region coming together is loosing its charm, simply because villages such and Samjhong and Dhe are simply not able to spare much grains to the festival. According to Pasang Gurung:

“..and now our tradition, in our main festivals yartung and loshar, we collect some wheat and grains to make chang and alcohol. Now we do not have enough food to feed us how can we contribute to the village fest? Yes our festivals and celebration are all affected and its slowly vanishing" (Devkota: 2011:9'). declining population is also a major concern affecting the cultural pattern. There were 24 
households in Dhe Village before and now 10 families have migrated to other areas and according to the mountain traditions they celebrate all the main festivals in community. Pasang Gurung points out that

"the village looks quiet and deserted... we feel sad in our festivals because we do not have enough people to celebrate it together. As our festivals are not meant to be celebrated with just 1-2 person, it would be nice if we can celebrate with all friends and families" (Devkota 2011:45').

Dhe Villagers celebrate a festival called dhimpuche also known as yartung for the children below 13 years. All the children of the village gather in the pine tree (see figure 7 in Annex) that is at the top of the village with the village lama and offer some pujas and celebrate it with a feast of thin bread that looks like pancake. This festival is only celebrated in Dhe Village in the whole of Lo-pa region so it is a unique tradition of Dhe villagers. The children of migrated family are not able to celebrate this festival elsewhere because the part of the festival also involves the exact pine tree of the village. If the villagers resettle in Thangchung as planned it may not be possible for the villagers to continue with this tradition. Skepticism shows is seen on the villagers as Topri Gurung states "it will be a long distance walk for the children, I can't it say now....but no matter what, we have to follow the tradition" (Devkota 2011:37'). Cultural identity will always be at risk in displaced and migrated communities and they may even find it hard to keep up with their practices. Oliver-Smith explains "the loss and destruction of cultural sites, shrines, and religious objects, and the interruption of important scared and secular events and rituals, undermines the community's sense of self" (Oliver-Smith 2009:123). It is really important to understand Oliver-Smith's statement because Dhe villagers may have the same problem in coming years and some are already happening. After the experience of loss the transition and process of recovery is never an easy thing socially, economically and psychologically.

Polyandry marriage practice may also be affected by climate change. Polyandry marriage within brothers of the same family keeps the limited land intact to the family, and the work division of looking after cattle, land and household was keeping the harmony in the family. The decline in cattle number and cultivating land and migration has forced people to abandon the polyandry marriage. There may be other factors such as modernization related to it, but it can also be linked to climate change when closely observed.

Karma's Case:

During my research I met Karma Gurung (60/male) who is from Dhe Village. His story represents the changing pattern of life and culture among semi-nomadic people of the region. Following story is based on the recorded interview with Karma Gurung in his tent dwelling on the banks of Dhe river (see figure 7). 


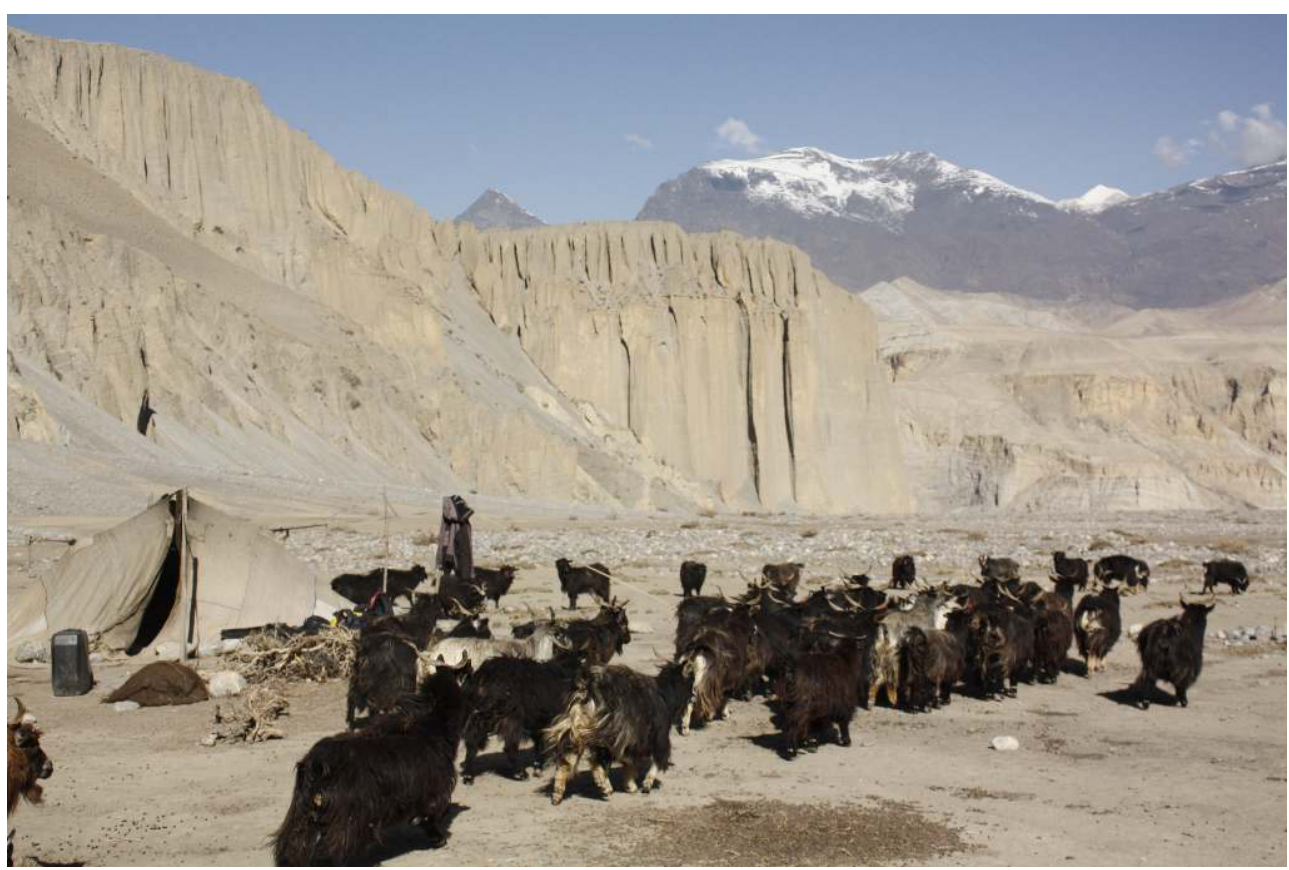

Karma Gurung's mother was a jhuma (a middle daughter of the family who is sent to the monastery to serve the god). Jhuma's life is in a way similar to those of 'ani' or the female monks. Karma's mother had a forbidden-relationship with a man from another village and got pregnant. Karma is a nylbho or the illegitimate one. She was forced to leave the convent and came to live in her village (Dhe) with the baby. Every jhuma gets a piece of land from the family which she can use it for her lifetime, according to the tradition the land is return to the brothers of jhuma after her death. Karma lived with his mother and worked on the field and few cattle before his mother died. After her death he returned the land to his maternal uncles and he was left only with small number of cattle. From that time till today he and his wife Heshe Wangmo Gurung (49) with five children live a semi-nomadic life with their cattle. The rapid decline in grazing grass is forcing them to sell their cattle and they have no other way to support their livelihood. Without any piece of land to work on and declining numbers of their animals - how will Karma's family sustain? There are many cases like of Karma in the region whose not just culture and tradition but also sole existence is in danger due to change - A fact verified by the study of nomads and pastoralism in Upper Mustang by Pandey and Chetri (2005).

\section{Migration}

51 The tax document of 1751 shows the record of 16 tax-paying households at the time (Dhungel 2002:19), and after two hundred sixty years, there are only 24 household in the village out of which ten family have already migrated elsewhere. According to the census of 2001, Nepal had a population of 23.15 million with annual growth rate of 2.25 per cent (Census 2001). According to the data provided by Dahal and Central bureau of Statistics (CBS) the population of Mustang in 1961- 33,600, 1971-29,944, 1981-12,930, 1991-14,319 and in 2001-14,981 (Dahal 2008 and CBS 2009). The statics and census proves that the region of Upper Mustang the population is on constant move and decline. 
Figure 8. A migrated family living in Tsarang

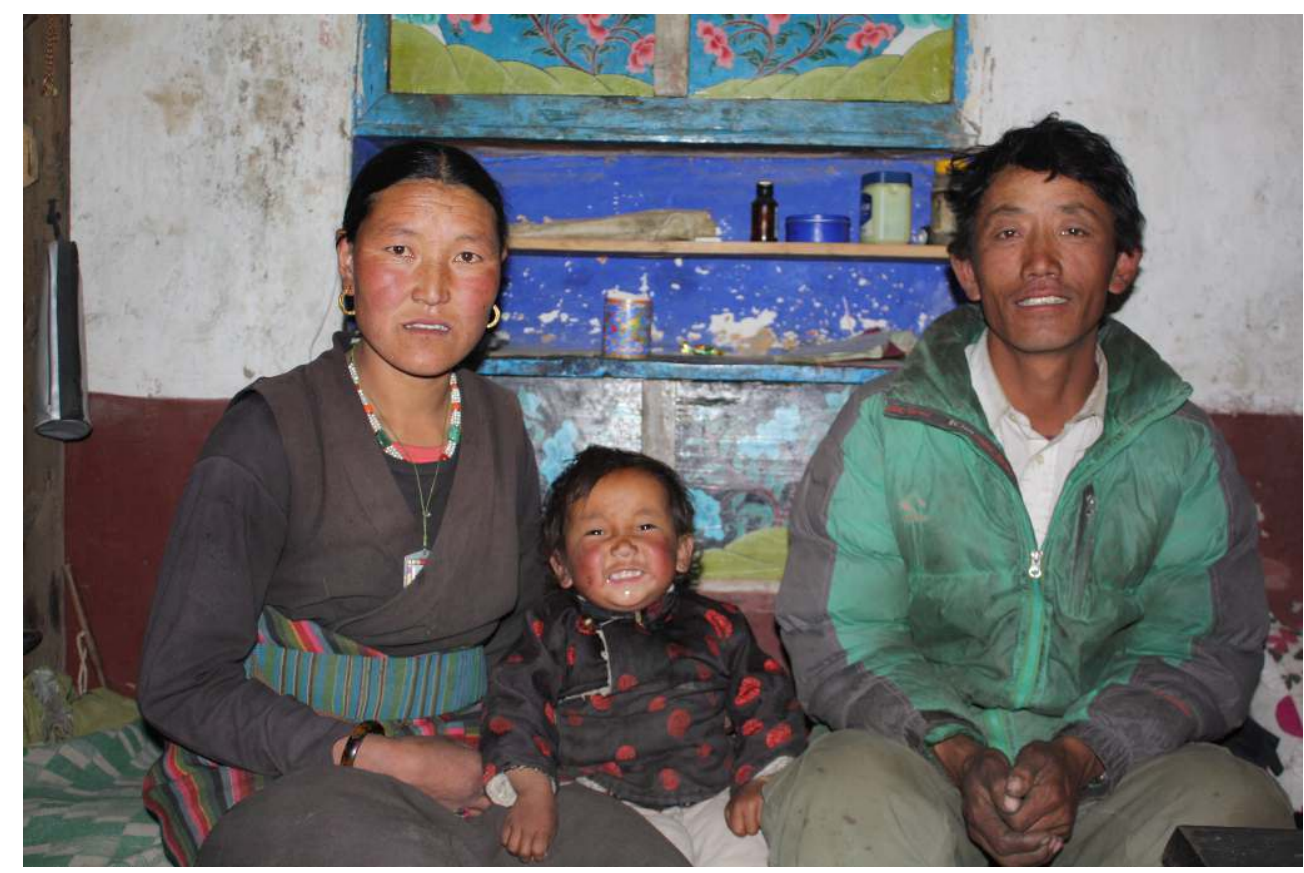

52 Tecoli defines the phenomenon of migration as an "adaptive response to socio-economic, cultural, political and environmental transformation, in most instance closely linked to the need to diversify income source and reduce dependence on natural resource" (Tacoli 2011:3), which is the reason for the migration of Lo-pa people from the region. It is also common for the people living in fragile and changing environment because their livelihood gets affected with the variation in climate conditions and there is always the struggle of survival. In the case of Dhe villagers except for three families, seven families have moved to nearby locations on the same region where they have existing networks of friends and relatives.

53 It is believed that most of the Lo-pa people migrated from Tibet (Dhungel 2002), and after the annexation of Tibet by China, the number has almost come to a halt. The strong presences of Chinese force in the border have deprived Lo-pa people of using the alpine pasture in the frontier region of Tibet, which they have been using for centuries (Dhungel 2002). Decrease in food production and decline in cattle herd is pushing Lo-pa people to migrate even though the mountain communities have a deep understanding of natural hazards and have knowledge of reducing the likelihood of tragic events (Blyth et al. 2002) things are happening to soon to fast for them to cope up with and the local knowledge in not working anymore.

Remaining 14-house hold of Dhe village wants to move to Thangchung and the preparation is already underway on community level. They have planted fruit and timber trees. Villagers told me that they are planning to make 24 houses for all the villagers, even for those who left for almost all of them can't wait to reunite with the friends and the families. As an anthropologist/activist I am, with my research reflecting/assisting on the "multidimensional nature of the impacts of climate change and to the adaptive response of humans to these impacts" (Roncoli et al. 2009:103), and migration is one of the last resort. 


\section{Other findings}

55 The most significant finding of my field research is the impact of annexation of Tibet by China in 1951 and its impact in the Himalayan region of Nepal. After the Cultural Revolution and Chinese rule of Tibet, there was influx of Tibetan refugees who migrated to the region with thousands of cattle. This caused an acute shortage in the pastureland. The armed Tibetan Khampa Guerillas (1957-1960) made the situation worst as they exploited the villagers and their land in Upper Mustang and Manang region. Most of the villagers have bad memories of the Tibetan Khampa warriors. Pasang Gurung like other villagers believes that the current climatic problem may be related to Tibetan Khampas. Pasang Gurung explains "in our ancestor's time, they say that there used to be lots of trees in our area which was all cut down and destroyed by the Khampas" (Devkota 2011:7') for their use sometimes using means of violence. Villagers believe that the deforestation may also be related to the current situation.

Figure 9. Water Mill and Solar Mill (Past and Present)

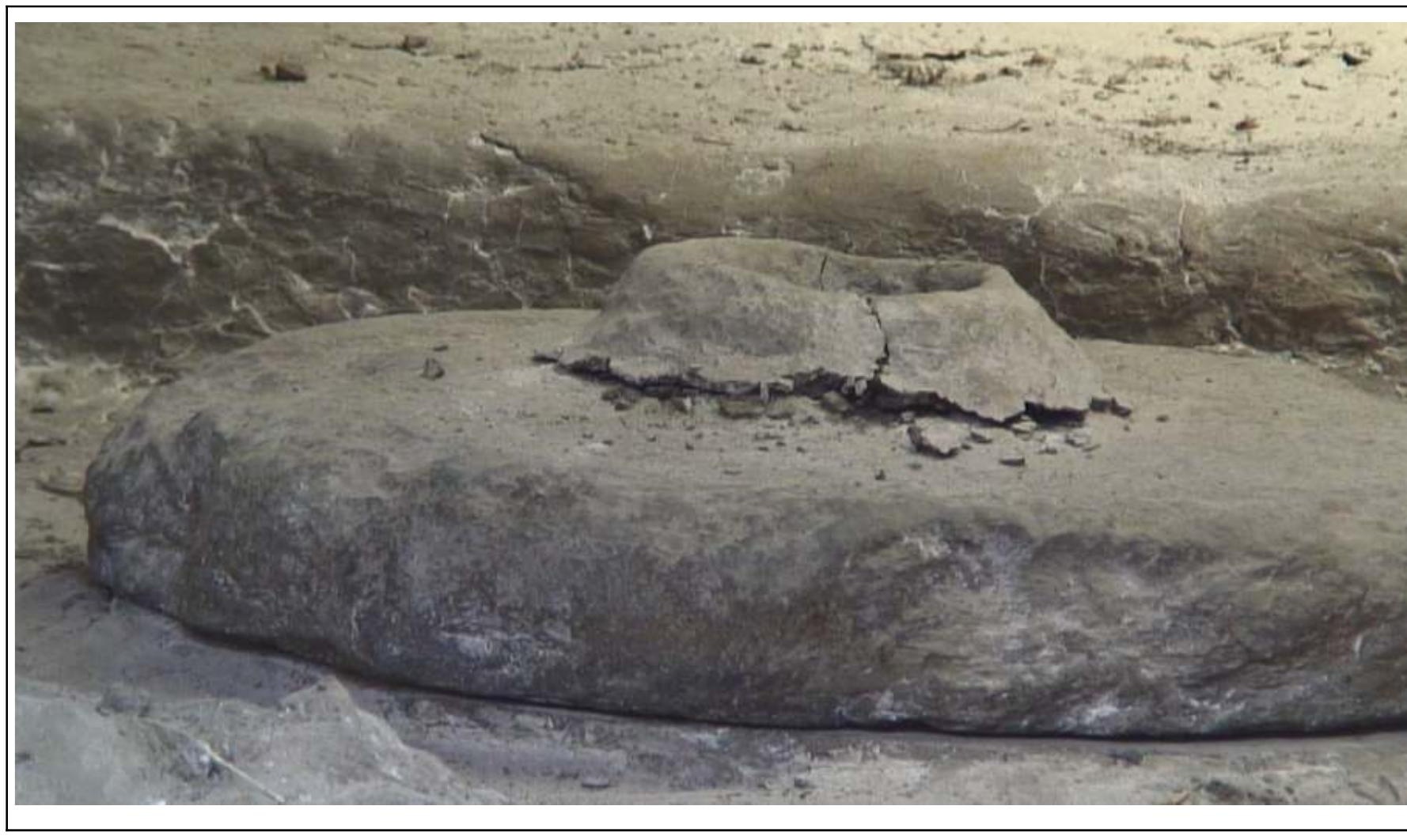




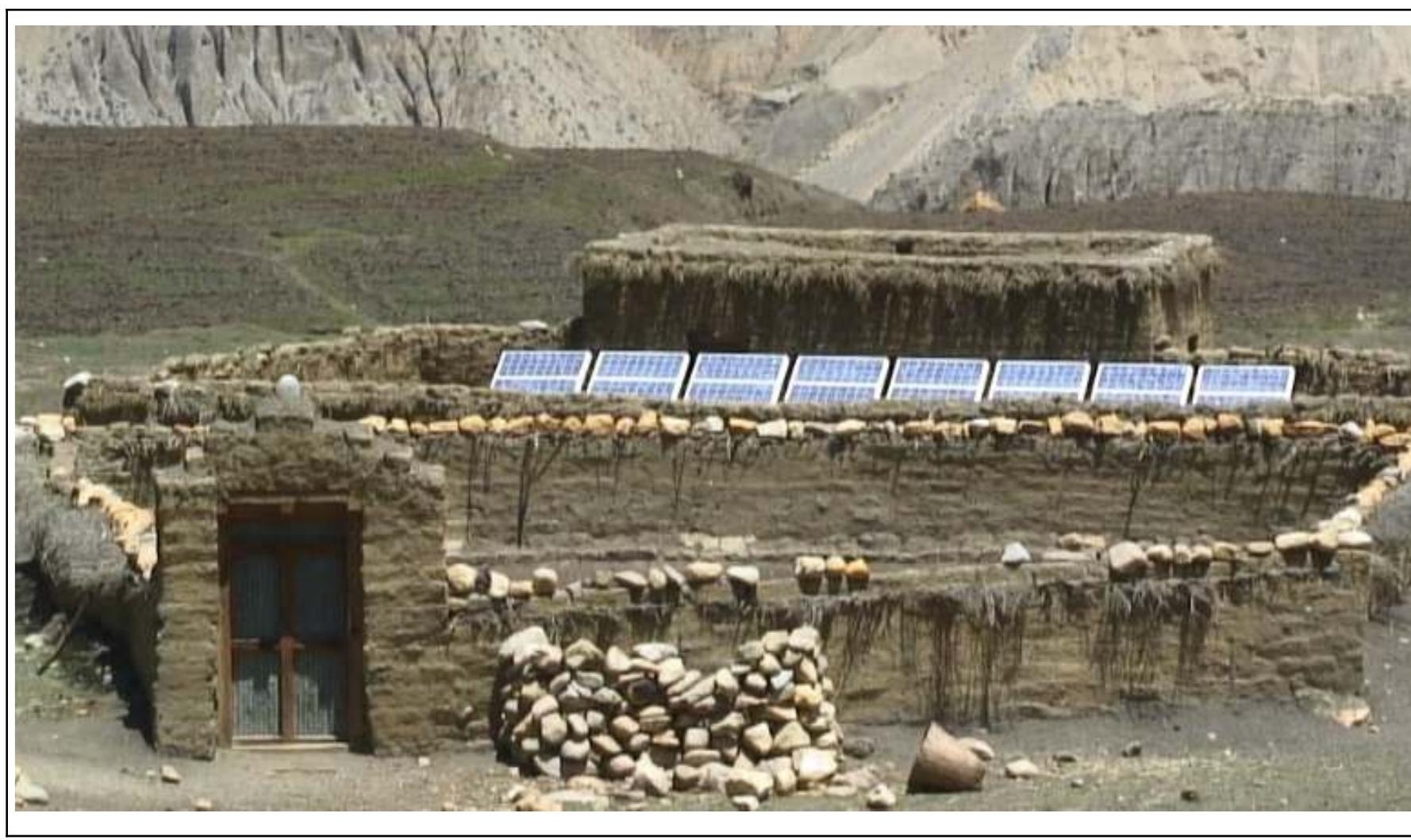

There is a small deserted water mill just below the lakes used for collection of water. People do not use it anymore because there is not enough water to run the mill. ACAP has installed a few solar panels to run an electric mill for the villagers (see figure 9). Village mukhiya (chief) Tsonam Tsering operates it and he keeps the key to the facility. If villagers need to use it, they ask Tsonan Tsering. Use of the facility is free. Other important contribution of ACAP is the distribution and installation of solar panels for electricity in every household. Solar electricity with energy saving bulbs has replaced oil and kerosene lamps, and burning of smoky woods and animal dropping. This has a positive impact on the health of the villagers. Solar instillation is the only thing representing modern time in the village. There are no radios, televisions, or telephones in the village. In other places like Lo-Manthang, Tsarang there are satellite dish for televisions from Nepal and Tibet in few households and these places also have telephone connections. Dhe villagers walk 2-3 hours to nearby village of Tsarang or Tangya to use telephone service. Tangya is the village where most of the Dhe villagers have matrimonial relationship. Dhe villagers and villagers have good relationship and help each other in agriculture and farming and now if Dhe villagers move to Thangchung as planned, that may change because of the distance.

\section{Dead - Aid}

As the villagers are struggling to sustain their livelihood, there are no substantial relief programs/planning from the government or non-government agencies. There is one nonfunctioning water-tap (see figure 10) in the village built by Care Nepal in 1996 and Solar panels installed by Annapurna Conservation Area Project (ACAP). ACAP has also helped 
villagers with 400 apple plants for the orchard at new resettlement area of Thangchung. Other presence of NGO's and INGO's is almost non-existent in the region.

Figure 10. A non-functional water-tap in the village

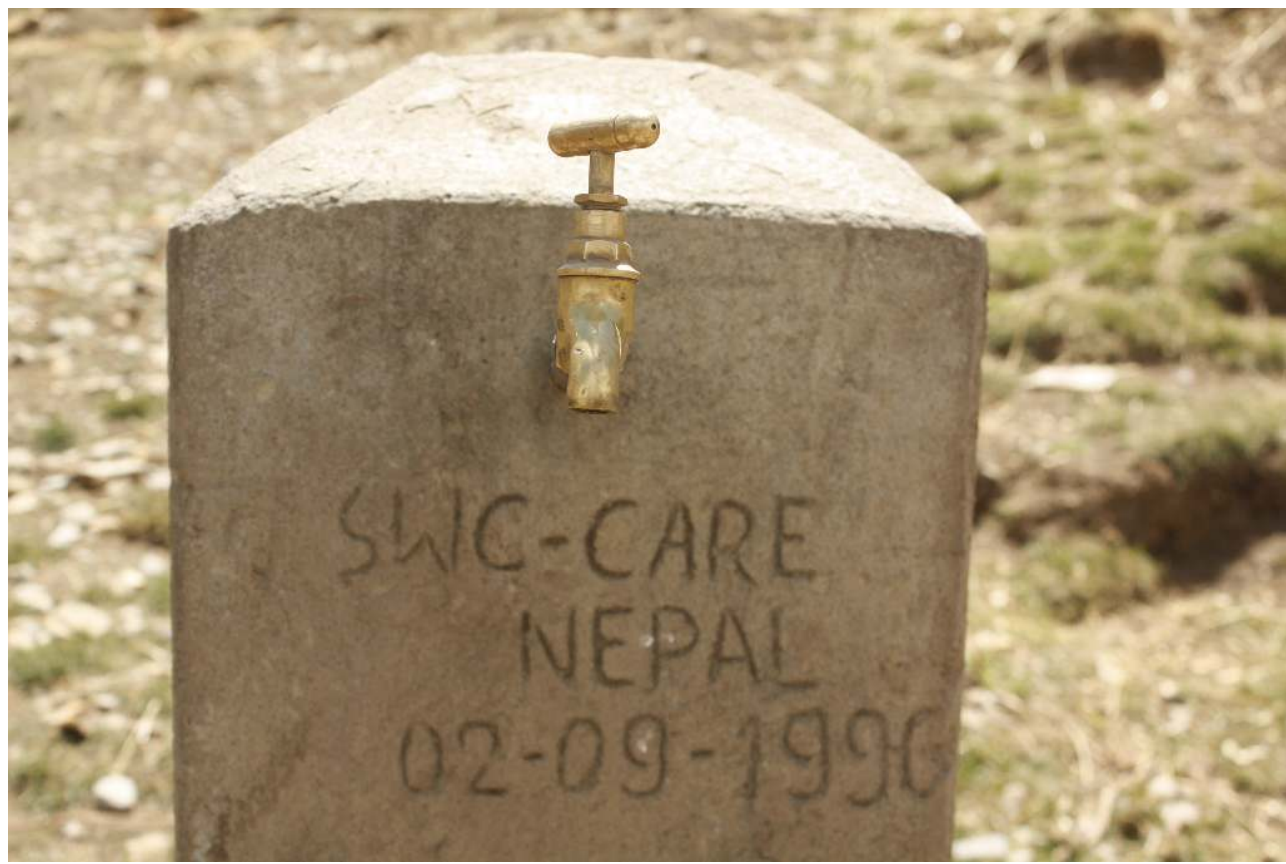

When I was in Kathmandu, I found out there are many INGO's and NGO's working on climate change issues. According to the Oxfam report the significant donors such as The United Kingdom Department for International Development (DFID), the Danish Department of International Development (DANIDA) and the United Nation Development Programme/Global Environment Fund (UNDP/GEF) are involved in assisting the Government of Nepal in Governments action on Climate change (Oxfam 2009). United Nation is also assisting government on National Adaptation Programme of Action (NAPA). There are non-governmental organization such as World Wildlife Fund (WWF Nepal), International Center for Integrated Mountain Development (ICIMOD), Oxfam Nepal, Deutsche Gesellschaft fuer Internationale Zusammenarbeit (GIZ), Care Nepal, Practical Action Nepal, Lutheran World Foundation, Action Aid, World Vision and Save the Children Alliance taking some initiatives to understand the impact of climate change from community perspective (Gum et al. 2009), but they are limited to certain part of the country and people in dire need of assistance are not getting anything.

Shrestha's interesting analysis of development and foreign aid scenario of Nepal in his book 'In the name of development' is important to understand to analyze the situation of Upper Mustang.

"In a country like Nepal, development is rarely a cumulative process, evolving indigenously through its symbiotic interaction with the expanding base of local knowledge and resources. It is predefined and predetermined in accordance with the Westerners' assumption of superiority of their economic rationality, imbued with techno-fetishism. It is this overt emphasis on the presumed superiority of Western economic rationality that has led to the total devaluation of the local modes of life and economics, consequently breeding and nurturing the culture of dependency and dependent development in Nepal" (Shrestha 1997:22). 

because they haven't seen substantive help up until now and they are using their own unique local knowledge in mitigation and adaptation.

The money generated by the Government of Nepal by offering special permit and visa to visit Upper Mustang sums up to millions of Nepalese Rupees. For Decades people of Mustangs are trying to get some amount of that money generated through such permits, but all in vain. Even if the Government sends the promised amount of the collection to Upper Mustang, it will be enough to assist locals with their development, health, education and livelihood. Lo-pa people aren't even receiving what actually is theirs. It is quite abstract as Banks says "how and under what conditions" (Banks 2001:129) do we the activist and social researchers negotiate with the concerned authority even if we have the trust of the people we are representing? It is a complex issue because we also need to think about what Spivak says, "Can subaltern speak" (Spivak 1988)? Vain

According to the fact presented by Dhungel in his book 'The Kingdom of (Lo) Mustang', Kathmandu has never been fair to the Lo-pa people of Upper Mustang (Dhungel 2002) and whatever is happening today is the continuation of it. I think time has come for the government and aid intuitions to understand the true meaning of development which "is after all more then just a matter of constructing roads and factories, fancy hotels and hospitals, huge dams and palaces, telephone lines and television networks... development involves building (or destroying) mutually supportive human relations to uplift humanity, all humanity, not just a select few" (Shrestha 1997: xxi).

\section{Epilogue}

The environment will continue to change sometime slow sometime fast, partly due to human activities with their effects both intentional and unintentional, and partly due to natural causes (Lamb 1982). But human societies have long records of "adapting to the climate risks and climate changes, management of climate fluctuation continues to be costly, inadequate, and ineffective in mitigating humanitarian disasters" (Heltberg et al. 2010: 259) and "anthropologists are strategically well-placed to interpret it, communicate information about it, and act in response to it both in the field and at home" (Crate 2008:569), so it becomes my duty as a filmmaker/ anthropologists to look closely at the socio-cultural implications of the changes that global warming has and is bringing (Crate and Nuttall 2009:13).

There is a distinct void of the information of the Himalayan region in the outside world and a research like this may bridge the gap. I firmly believe that a further study on the area is a must to assist the policymakers, because Nepal doesn't have potential to adapt to climate change and it lacks plans and policies at national level. The reason for me undertaking the research is as Rouch said "For whom, and why, do I take the camera among mankind? My first response will always, strangely, be the same: 'For me"' (Rouch 2003: 43). And the focus here is not just the exploration of the region with the camera but rather on the presentation through film of an anthropological view or statement of, and about the region (Ruby 1975:104) in the time of social transformation. All researchers are to some degree connected to, a part of, or the object of their research (Davies 1999:3), and as a member of mountain community myself it was natural for me to get involved in the understanding and well-being of my own community. As Ruby said "what anthropologist 
has to offer is primarily a systematic way of understanding humanity- our as well as everyone else's" (Ruby 1980:161).

\section{BIBLIOGRAPHY}

Agar, Micheal H. 1980. The Professional Stranger: An Informal Introduction to Ethnography. New York: Academic Press.

Ahmed, Nilufar, Hari B. Dalal and Samantha L. Forsuz. 2009. "The Social Dimension of Climate Change." In South Asia: Shared Views on the development and Climate Change. ed. South Asia RegionSustainable Development Department World Bank. 131-137. Washington DC: World Bank.

Anderson, Simon, John Morton and Camilla Toulmin. 2010. "Climate Change for Agrarian Societies in Drylands: Implications and Future Pathways." In Social Dimensions of Climate Change. eds. Robin Mearns and Andrew Norton. 259-275. Washington DC: The International Bank for Reconstruction and Development/The World Bank.

Asch, Timothy. 1992. “The Ethics of Ethnographic Film-making." In Film as Ethnography eds. Peter I. Crawford and D. Turton, 196-204: Manchester: Manchester University Press.

Baidya, Saraju K., Ramesh K. Regmi and Madan L. Shrestha. 2007. "Climate Profile and Observed Climate Change and Climate Variability in Nepal." Kathmandu: Department of Hydrology and Meteorology, Ministry of Environment Nepal.

Banks, Marcus. 2001. Visual Methods in Social Research, London and New Delhi: Sage Publications.

Bernard, H. Russell. 2011. Research Methods in Anthropology. Plymouth: AltaMira Press.

Blyth, Simon, Brian Groombridge, Igor Lysenko, Lera Miles and Adrian Newton. 2002.

"Environmental Change and Sustainable development in mountains." In Mountain Watch. United Kingdom: UNEP World Conservation Monitoring Center.

Butterbury, Simon. 2008. "Anthropology and Global Warming: The Need For Environment Engagement." The Australian Journal of Anthropology 19(1): 62-65.

Cassell, Joan. 1980. "The Principles of Conducting Fieldwork." American Anthropologist. New Series Vol. 82(1): 28-41.

CBS. 2004. Nepal Living Standard Survey 2004. Kathmandu: Central Bureau of Statistics.

Central Bereau of Statics.1991. Census 1991 National Report, National Planning Commission Secretariat. Government of Nepal.

Central Bereau of Statics. 2001 Census 2001 National Report, National Planning Commission Secretariat. Government of Nepal.

Crate, Susan A. 2008. “ Gone the Bull of Winter.” Current Anthropology 49(4): 569-595.

Crate, Susan A. and Mark Nuttall. 2009. "Introduction: Anthropology and Climate Change." In Anthropology and Climate Change. eds. Susan A. Crate and Mark Nuttal, 9-36. California: Left Coast Press. 
Cruz, R.V., H. Harasawa, M. Lal, S. Wu, Y. Anokhin, B. Punsalmaa, Y. Honda, M. Jafari, C. Li and N. Huu Ninh, 2007. " Asia. Climate Change 2007: Impacts, Adaptation and Vulnerability. Contribution of Working Group II to the Fourth Assessment Report of the Intergovernmental Panel on Climate Change," eds. M.L. Parry, O.F. Canziani, J.P. Palutikof, P.J. van der Linden and C.E. Hanson,469-506: Cambridge: Cambridge University Press. 469-506.

Dahal, Dilli R. 2008. “Anthropology of the Nepal Himalaya: A critical Appraisal.” In Anthropology of Tibet and the Himalaya. eds. Charles Ramble and Martin Braunen. Kathmandu: Vajra Publications.

Davies, Charlotte Aull. 1999. Reflexive Ethnography: A Guide to Researching Selves and Others. London: Routledge.

Devkota, Fidel. 2011. Shambala: A story of Paradise Lost. 50 mins. Nepal/Germany: n.d.

Dhungel, Ramesh K. 2002. The Kingdom of Lo (Mustang): A Historical Study. Kathmandu: Tashi Gephel Foundation.

Donner, Wolf. 1968. Mustang, Observations in the Trans-Himalayan Part of Nepal. Kathmandu: Government of Nepal.

Fagan, Brian. 2005. The Long Summer: How Climate Changed Civilization. London: Granta Books. Froemming, Urte Undine and Christian Reichel, 2011. "Vulnerable coastal regions. Indigenous People under Climate Change. In Religion in Global Environmental and Climate Change. Sufferings, Values, Lifestyles eds. Gerten, Dieter, Bergmann, Sigurd, 215-235: London: Continuum.

Fuch, Peter. 1988. Ethnographic film in Germany: An Introduction. Visual Anthropology. I: 217-233. Gardner, Robert. 1957. Anthropology and Film. Daedalus Vol. 86(4): 344-352.

Grimshaw, Anna. 2005. “New Horizons for Visual Anthropology.” In Visualizing Anthropology eds. Anna Grimshaw and Amanda Ravetz, 17-30: Bristol and Portland : Intellect Books.

Gum, Wayne, Prabin Man Singh and Beth Emmett. 2009. "Even Himalaya have stopped smiling: Climate Change, poverty and Adaptation in Nepal". Kathmandu: Oxfam International.

Hagen, Toni. 1998(1961) Nepal (revised and updated). Kathmandu: Himal Books.

Haimendorf, Christopher von Furer. 1964. The Sherpas of Nepal. Barkeley: University of California Press.

Hamilton, Francis Buchanan. 1971(1819). An Account of the Kingdom of Nepal and of the Territories Annexed to the Dominion of the House of Gorkha. Reprint. New Delhi: Manjusri Publishing House.

Hassan, Fekri A. 2009. "Human agency, climate change and culture: An archaeological perspective." In Anthropology and Climate Change eds. Susan A. Crate and Mark Nuttall, 39-69. California: Left Coast Press.

Heltberg, Rasmus, Paul Bennett Siegel and Steen lau Jorgensen. 2010. "Social Policies for Adaptation to Climate Change." In Social Dimensions of Climate Change. eds. Robin Mearns and Andrew Norton. 259-275. Washington DC: The International Bank for Reconstruction and Development/The World Bank.

Hodgson, Brian. 1972 (1874). Essays on the Languages, Literature and Religion of Nepal and Tibet. Reprint. New Delhi: Manjusri Publishing House.

Kawaguchi, Ekai. 1979 (1909). Three years in Tibet. Reprint, Kathmandu: Ratna Pustak Bhandar. Krikpatrick, William. 1975 (1811) An Account of the kingdom of Nepaul, Being on the substance of Observation made during the Mission of the Country in the year 1793. Reprint. New Delhi: Asian Publication Services. 
Lamb, Hubert. 1982. Climate, History, and the Modern World. Oxford and New York: Routledge. MacDougall, David. 1975. "Beyond Observation Cinema.” In Principles of Visual Anthropology ed. Paul Hockings. 109-124: The Hague: Mouton.

MacDougall, David. 1992. "Complicities of Style”. In Film as Ethnography eds. Peter Ian Crawford and David Turton, 140-149. Manchester: Manchester University Press.

MacDougall, David. 1998. Transcultural Cinema. Princeton New Jersey: Princeton University Press.

Mead, Margaret. 1995. "Visual Anthropology in a Discipline of Words". In Principles of Visual Anthropology, ed. Paul Hockings, 3-10. Berlin; New York: Mouton de Gruyter.

Monagham, John and Peter Just. 2000. Social and Cultural Anthropology. Cornwell and New York: Oxford University Press.

Nastasi, Bonnie K.. 1999. “Audio Visual Methods in Ethnography.“ In Enhanced Ethnographic Methods. Eds. Jean J Schnesul. Margaret D. LeCompte, Bonnie K. Nastasi and Stephen P. Borgatti, Plymouth: AltaMira Press.

Neupane, Ishwori and Lalprasad Sharma. 2011. "Upper Mustang out of bounds? " ekantipur. Accessed on Oct. $2^{\text {nd }}$ 2011. http://www.ekantipur.com/2010/08/28/national/upper-mustang-outof bounds/321301.html.

Nichols, Bill. 2001. Introduction to Documentary. Bloomington: Indiana University Press.

Oliver-Smith, Anthony. 2009. "Climate Change and Population Displacement: Disasters and Diasporas In the Twenty-First Century." In Anthropology and Climate Change eds. Susan A. Crate and mark Nuttall, 116-136. California: Left Coast Press.

Pandey, M.R. and M. Chetri. 2005. "Nomads and Pastoralism: Linkage with Conservation in Upper Mustang." Our Nature (3): 42-49.

Pelto, Gretel H. and Pertti J. Pelto. 1976. The Human Adventure: An Introduction to Anthropology, New York: Macmillian Publishing Company.

Pink, Sarah. 2006. The Future of Visual Anthropology: Engaging the Senses. London: Routledge.

Pokharel, Santosh and Dilip Poudel. 2011. "Upper Mustang locals threaten to bar tourist." Republica. Accessed on Oct. $2^{\text {nd }}$ 2011. http://archives.myrepublica.com/portal/index.php? action=news_details\&news_id=22419.

Rai, Sandeep Chamling and Aarati Gurung. 2005. "Raising Awareness of the Impacts of Climate Change: Initial steps in shaping policy in Nepal." Mountain Research and Development 25(4): 316-320.

Roncoli, Clara, Todd Crane and Ben Orlove.2009. "Fielding Climate Change in Cultural Anthropology." In Anthropology and Climate Change, eds. Susan A. Crate and Mark Nuttall, 87-115. California: Left Coast Press.

Rouch, Jean. 2003. Cine- Ethnography, trans. Steven Feld. Minneapolis: University of Minnesota Press.

Ruby, Jay. 1975. Is an Ethnographic Film a Filmic Ethnography? Studies in the Anthropology of Visual Communication 2, (2) (Fall): 104-111.

Ruby, Jay. 1980. “Exposing yourself: Reflexivity, Anthropology and Film.” Semiotica 30(1/2): 153-179. 
Schnesul, Jean J. Margaret D. LeCompte, Bonnie K. Nastasi and Stephen P. Borgatti. 1999. Enhanced Ethnographic Methods. Plymouth: AltaMira Press.

Shrestha, Arun Bhakta. 2009. "Climate Change in the Himalayas Information Sheet." Kathmandu: International Center for Integrated Mountain Development (ICIMOD).

Shrestha, Nanda R. 1997. In the Name of Development: A Reflection on Nepal. Kathmandu: Educational Enterprises (P) Ltd..

Spence, F. S. 1987. "Himalayan Survey.” The Geographical Journal Vol. 153(2): 223-230.

Spivak Chakravotry, Gayatri. 1988. "Can Subaltern Speak?" In Marxism and the Interpretation of Culture, eds. Cary Nelson and Lawrence Grossberg, 271-313. Urbana and Chicago: University of Illinois Press.

SYC (Saligram Yuva Club). 2011. Proposal on Resettlement and Development Plan of Dhe Village. Mustang: Surkhang Village Development Committee.

Tacoli, Cecilia. 2011. Climate Change and Migration. Eschborn: Deutsche Gesellschaft Fuer Internationale Zusammenarbeit (GIZ).

Tucci, Giuseppe. 1982 (1953). Journey to Mustang 1952. Trans By Diana Fussel. Second reprint. Kathmandu: Ratna Pustak Bhandar.

UNFCCC. 1992." United Nations Framework Convention on Climate Change." Accessed July 29th 2011 http://unfccc.int/essential_background/convention/background/items/2536.php.

Upadhayaya, Shyam K. “ Upland Poverty in Nepal: The Role of Environment.” Paper prepared for conference of The Environment of the poor in the context of Climate Change and the Green Economy: Making sustainable development more inclusive, New Delhi November 24-26, 2010.

Vertov, Dziga. 1929. Man With A Movie Camera. Soviet Union: VUFKU.

Waldram, James B. and Noel Dyck. 1993. “ Some Limits to Advocacy Anthropology in the Native Canadian Context." Anthropology: Public Policy and Native People in Canada, eds. James B. Waldram and Noel Dyck, 293-310. Montreal and Kingston: McGill-Queen's University Press.

Zurick, David N. 1989. "Historical Links Between Settlement, Ecology and Politics in the Mountain of West Nepal." Human Ecology Vol. 17(2): 229-255.

\section{ABSTRACTS}

There has been limited research on the cultural context in the Himalayan region of Nepal with true anthropological significance and very few based on environment and people. Himalayan region of Nepal was a forbidden land and was left untouched for political and geographical reason before 1950's. Sudden change in climatic pattern has threatened the livelihood of the rural poor. Clear indications of these impacts can be seen on Himalayan glaciers, which are melting rapidly. Understanding its impact on culture and people of our time and responding successfully to them will be a major test for mankind and civilization. This research is an effort with the role of activist, witness, advocate, and a medium to contribute to the societies of Himalayan region and elsewhere.

Il y a peu d'études anthropologiques significatives consacrées tant au contexte culturel qu'à l'environnement et à la population résidant dans la région himalayenne du Népal. Jusqu'en 1950, cette région était interdite et laissée pour compte pour raisons politiques et géographiques. Les changements climatiques soudains ont considérablement compromis les moyens d'existence des 
populations rurales pauvres. Les fontes rapides des glaciers de l'Himalaya sont les preuves évidentes de ces transformations climatiques. Comprendre les effets de ces altérations climatiques sur la culture et la population et pouvoir apporter des réponses satisfaisantes sont un des enjeux majeurs de l'humanité et de notre civilisation. Cette recherche vise à soutenir les groupes de la région de l'Himalaya et d'ailleurs en intervenant comme activiste, témoin, avocat et tout en relayant ce message. (cri d'alarme)?

Se han realizado escasas investigaciones antropológicamente significativas sobre el contexto cultural de la región del Himalaya, en Nepal, y muy pocas basadas en el medio ambiente y en la gente. La región del Himalaya en el Nepal fue una tierra prohibida y dejada de lado por razones políticas y geográficas hasta 1950. Las bruscos cambios climáticos han amenazado la forma de vida de las poblaciones rurales pobres. Los glaciares del Himalaya, que se están derritiendo con rapidez, son una prueba evidente de este impacto. Entender el impacto de estos cambios en la cultura y en la gente de hoy en día y aportar respuestas satisfactorias es una tarea crucial para la humanidad y la civilización. Esta investigación representa un esfuerzo donde se entrecruza el rol de activista, testigo, abogado y mediador para contribuir en la mejora de las sociedades de la región del Himalaya y de otras partes del mundo.

\section{INDEX}

Mots-clés: Nepal, Himalaya, environnement et population, fonte des glaciers, réchauffement anthropique de la planète, savoir local

Keywords: environment and people, melting glaciers, anthropogenic global warming, local knowledge

Palabras claves: medio ambiente y población, derretimiento de los glaciares, calentamiento antrópico del planeta, saber local

\section{AUTHOR}

\section{FIDEL DEVKOTA}

Institute of Social and Cultural Anthropology, Freie Universität Berlin 